\title{
Tips and Tricks in Experimental Nerve Defect Surgery
}

Andrei MARIN', Ruxandra Ioana MIHAI', Georgiana Gabriela MARIN²

\begin{abstract}
Microsurgery in itself might be considered a challenge for some plastic surgeons, as it requires patience and perseverance. Furthermore, when it comes to nerve surgery, the challenge is even greater as it implies a longer time necessary to observe results. In clinical practice, a good technique is associated with a good outcome. However, the problem of the recovery time remains an issue to be addressed by future generations.

Nerve defects represent an even greater challenge in traumatology. Crush injuries, lacerations and avulsions may all lead to irreversible damage of the nerves. In such cases, special surgery techniques are required to restore function ${ }^{1-4}$. In order to prepare for these special techniques, a surgeon must begin with experimental in vivo nerve surgery and one that has the highest similarity with humans is the sciatic nerve of the Wistar rat ${ }^{5}$.
\end{abstract}

Keywords: sciatic nerve defect, rat model, experimental surgery, nerve tubes.

\section{Rezumat}

Microchirurgia constituie o provocare pentru unii chirurgi plasticieni, aceasta necesitând răbdare și perseverență. Când vorbim de chirurgia nervilor periferici, provocarea este cu atât mai mare cu cât implică o perioadă mai lungă de recuperare, pentru a putea vedea rezultatele. În practica clinică, o tehnică bună este asociată unor bune rezultate. Defectele nervoase constituie o provocare chiar și mai mare în traumatologie. Leziunile prin strivire, lacerațiile și avulsiile pot afecta în mod ireversibil nervii. Pentru a avea experiența necesară rezolvării acestor cazuri, un chirurg trebuie antrenat în chirurgia experimentală in vivo, iar cea mai mare similitudine cu omul o are nervul sciatic de sobolan Wistar.

Cuvinte-cheie: defect de nerv sciatic, chirurgie experimentală, șobolan Wistar, conductori nervoși.

\section{INTRODUCTION}

Although quite resistant to shear stress, nerves can be injured in different ways at different sites ${ }^{6,7}$. Nerve defects up to $0,5 \mathrm{~cm}$ can be sutured sometimes primarily, with proximal and distal dissection. However this results in higher tension in the suture, increasing the risk of nerve rupture and influencing the regeneration process. For this situation, coaptation of the nerve endings is better performed indirectly by using a nerve conduit ${ }^{8,9}$.

The theoretical knowledge of different types of nerve injuries helps to properly evaluate each case and decide upon specific actions ${ }^{10,11}$. A rigorous training in experimental microsurgery is to be performed before conducting sutures on humans, as there is a learning curve to be achieved ${ }^{12,13}$.

\footnotetext{
1 Department of Plastic Surgery, "Bagdasar Arseni" Emergency Hospital, Bucharest, Romania

2 Department of Cardiology, "C.C. Iliescu" Hospital, Bucharest, Romania
}

Corresponding author:

Andrei MARIN, Department of Plastic Surgery, „Bagdasar Arseni” Emergency Hospital, Bucharest, Romania.

e-mail: marin_dpt@yahoo.com 
One of the most suitable laboratory animals for in vivo experimentation is the Wistar rat, due to its high similitude in nerve regeneration; furthermore its availability ease for manipulation make the rat the ideal candidate for experimental microsurgery. What is more, the sciatic nerve in the case of the Wistar rat is easily accessible and has suitable size and length for different microsurgical procedures ${ }^{14}$. The sciatic nerve runs along the inferior border of the femur for $3 \mathrm{~cm}$ before dividing into 3 terminal branches - common peroneal, tibial and sural nerve ${ }^{15}$.

Apart from the surgical technique, good outcomes in the in vivo experiments depend on proper anesthesia ${ }^{16}$.

\section{MATERIAL AND METHOD}

Wistar rats in different microsurgery training laboratories were used. The weight of the rats varied between $250-350 \mathrm{~g}$ being of different ages ( 7 to 9 weeks). The anesthesia protocol consisted of a mixture of ketamine $(75 \mathrm{mg} / \mathrm{kg})$ and xylazine $(10 \mathrm{mg} / \mathrm{kg})$ administered intraperitoneally. For a correct dose administration, a scale was used to weigh every animal. In all laboratories, different microscopes with magnification varying between $3 \mathrm{x}-20 \mathrm{x}$ were used, as well as suitable microsurgical instruments appropriate sutures (8-0.9-0.10-0).

After administrating the anesthesia, the rats were shaved in the gluteal area and the thigh region and pla-



Microscope

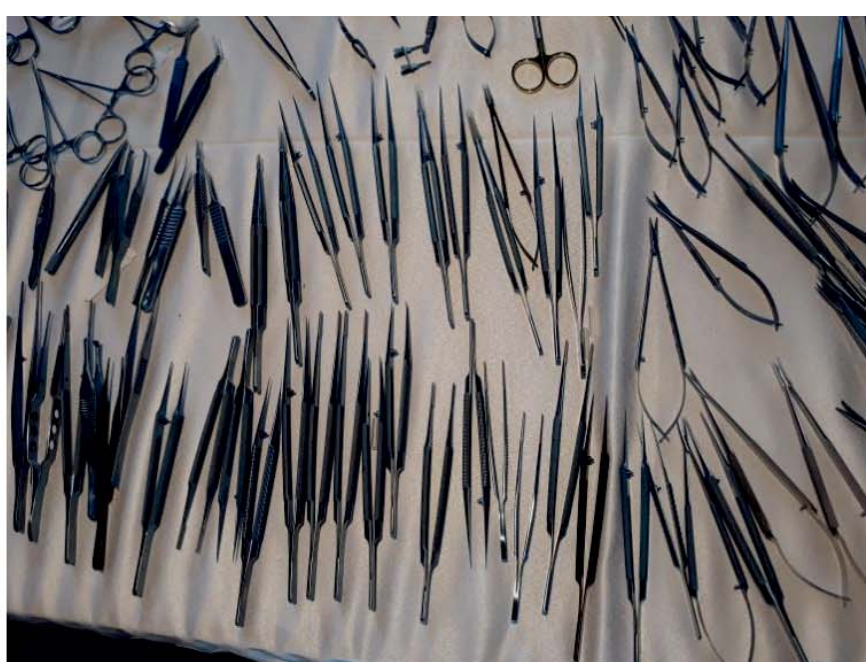

Microsurgical instruments

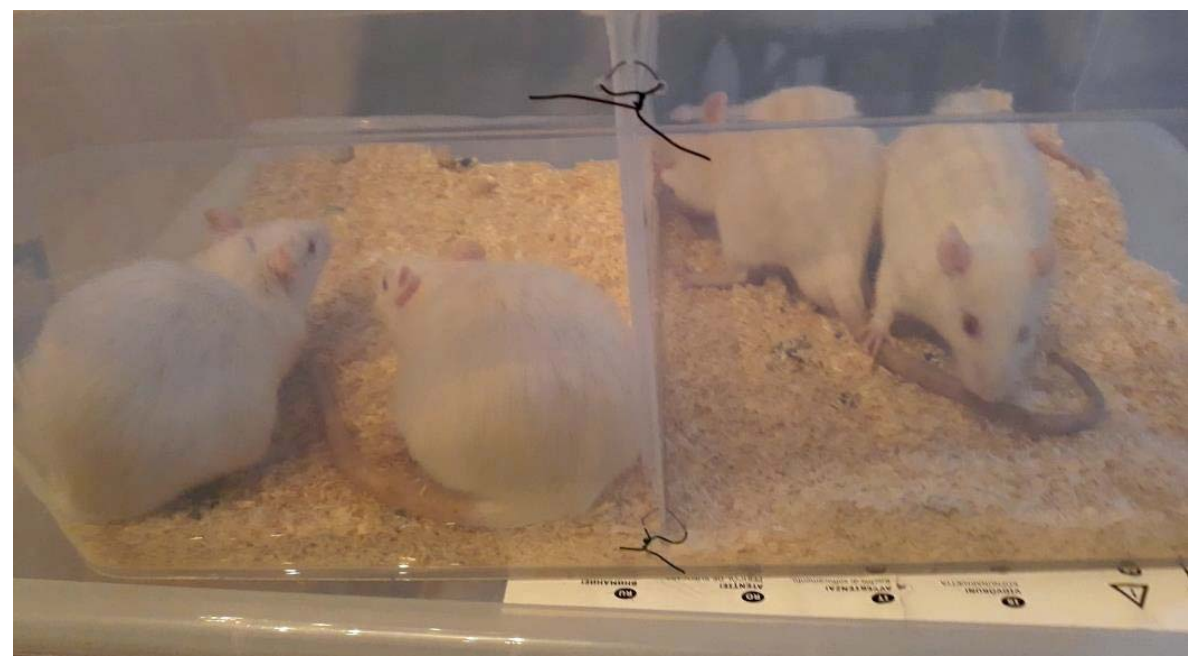

Wistar rats 
ced in prone position, with the limb to be operated on in extension. A syringe was placed under the hip joint in order to achieve maximal limb extension and to push the sciatic nerve more superficial. An oblique-transverse skin incision was made $1 \mathrm{~cm}$ inferior to the border of the femur and dissection through the biceps muscle fibers was performed in order to expose the underlying sciatic nerve.

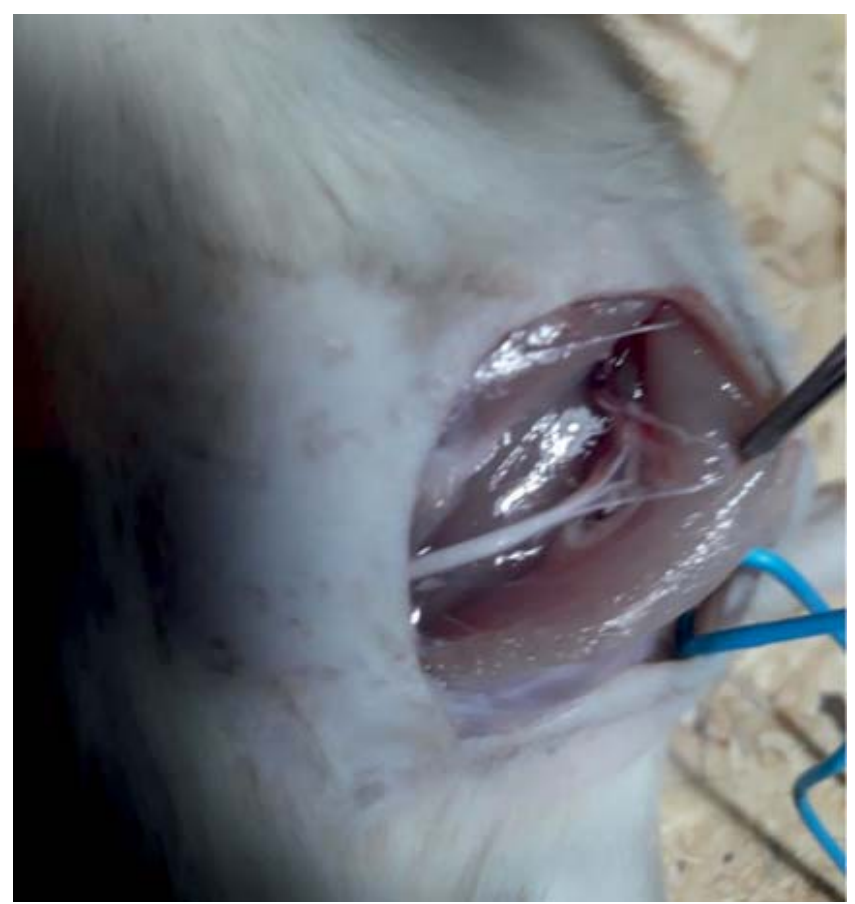

Sciatic nerve exposure

After creating a $0.5 \mathrm{~cm}$ nerve defect, a surgical repair using different procedures was performed. Some involved using a silicone tube, others a biologic vessel harvested from a rat. Both procedures require placing the nerve endings inside the conduit for $0.3 \mathrm{~cm}$ and $2-3$ sutures at both ends.

\section{RESULTS}

In all cases when a defect is involved, the nerve must grow through 2 different sites - proximal and distal. The outcome after nerve repair depends on the technique used, on the type of nerve conduit as well as on the type of the initial nerve injury. The regeneration speed of the sciatic nerve in rats is estimated at $1,5 \mathrm{~mm} /$ day and final results may be observed several weeks after the intervention. This growth rate may be increased by using different growth factors inside the nerve conduits ${ }^{17}$.

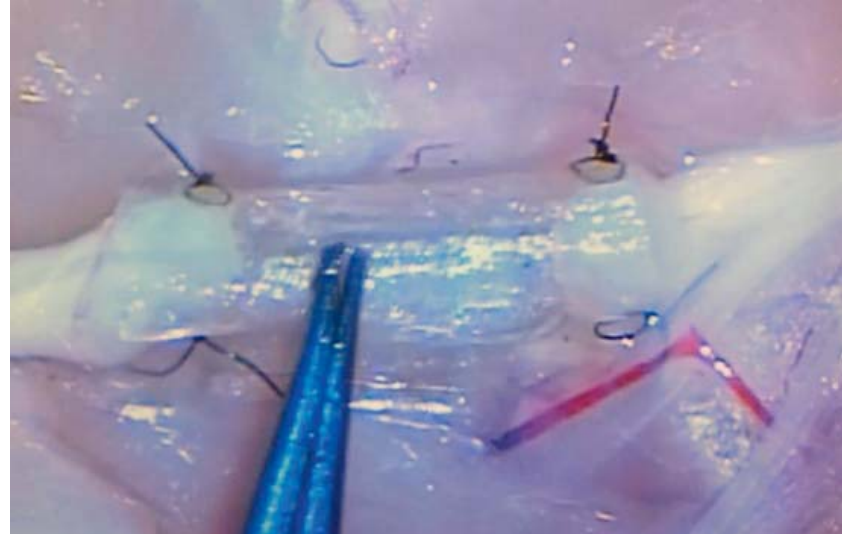

Sciatic nerve repair using a silicone tube

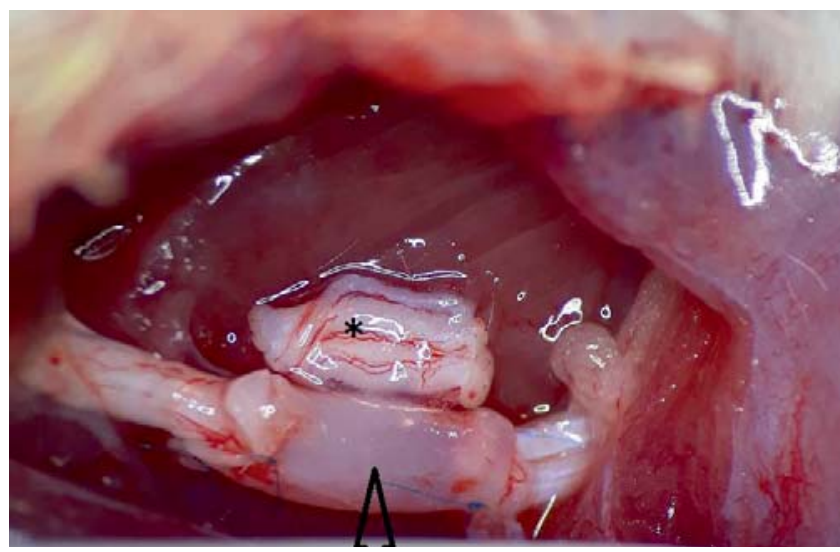

Sciatic nerve repair using aorta as nerve conduit (arrow - aorta; * - resected nerve to create the defect)

\section{DISCUSSIONS}

Choosing adequate size rats is important in order to have large enough nerves to practice the microsurgical technique. Therefore, it is recommended not to operate rats which are lighter than $250 \mathrm{~g}$ or younger than 7 weeks of age.

The exact dosage of anesthesia is vital to be administered in order for the animals to survive and to have a fast recovery (if a longer study is in question). When the correct dosage doesn't have the desired effect, it is better to postpone the operation and choose another rat if possible (multiple doses may cause respiratory distress which can finally kill the lab animal).

Synthetic nerve tubes represent a good therapeutic option for nerve defects. They do not require a prior intervention for harvesting; their lumen is generally open (no external growth resistance) and can be filled with different growth factors. They can be manufactured to 

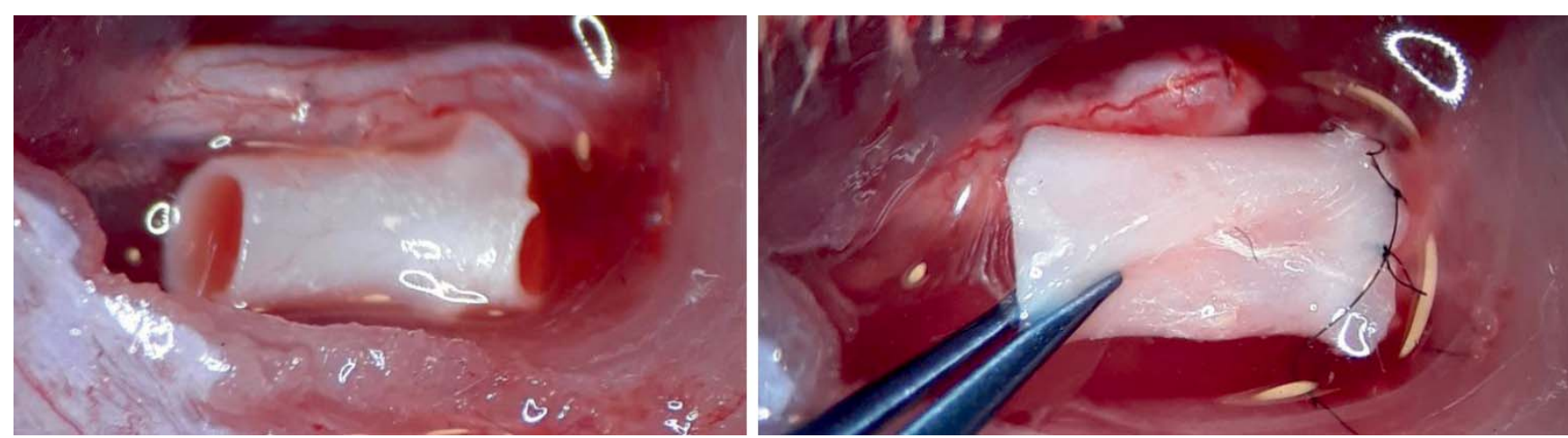

Aortic conduit harvested from another rat (notice the larger caliber of the conduit in comparison to the nerve). Suture at regular intervals prevent the notching

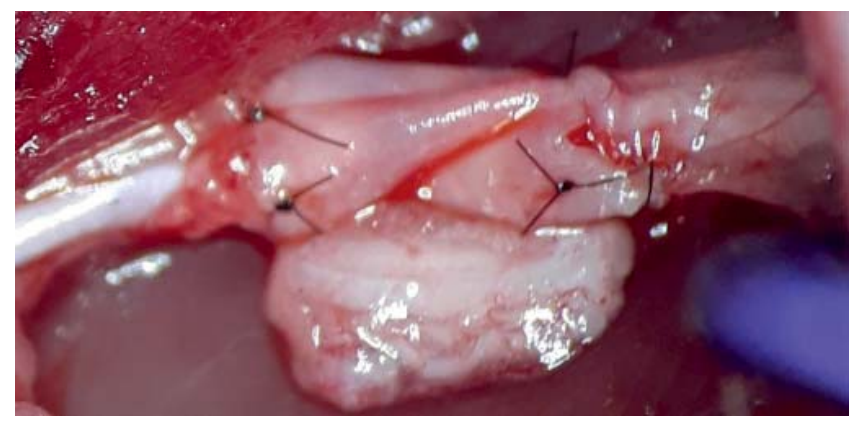

Notching and twisting of the aortic conduit due to improper placement of the sutures

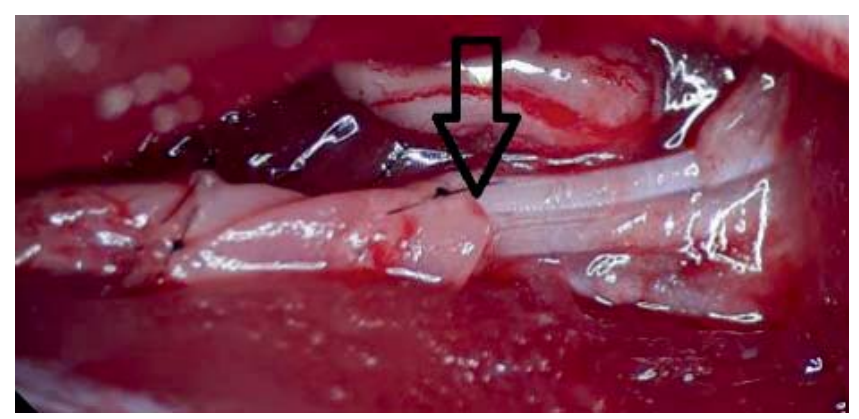

Small caliber artery adjusted by a fishmouth incision (arrow) to fit the nerve inside the lumen

be suitable for every nerve size. The disadvantages of synthetic tubes are that they are expensive and they might generate a foreign body reaction. Furthermore, their structure can be rigid and when they don't have the right size, they may not be adjusted to nerve diameter.

In comparison to synthetic tubes, vessel conduits are easily accessible and abundant. When harvested from the same rat, these generate little inflammation, but no foreign body reaction. Due to the elasticity of their walls, veins can be adjusted to fit different nerve sizes. The major problem with veins is that they tend to collapse, making it difficult for the nerve to grow to reach the distal ending. A solution for this issue is to fill their lumen with either muscle fibers or different growth factors, in order to keep the lumen open ${ }^{18}$. Manoli et al showed no difference between nerve autografting and muscle in vein conduits for defects of the digital nerves ${ }^{19}$.

Arteries can also be used as nerve conduits. They are scarcer to find and when harvested may result in some degree of functio laesa but they have the advantage of a relative rigid wall, keeping the lumen open. Therefore they can be more easily filled with semiliquid substances (nerve factors) that remain inside. The difference in caliber in comparison to the nerve may determine notching of the vessel. To prevent this, equally distanced sutures on the circumference of the vessel should be performed.

In case of a small caliber artery to be used as a nerve conduit, this can be adjusted by making fishmouth incisions in order to fit the nerve endings inside the lumen.

Although nerve conduits may be used to bridge a nerve gap and facilitate grow-through process, autografts/allografts have similar result and are frequently used in nerve defects; there are however pitfalls in using either methods, which need to be kept in mind when dealing with nerve defects ${ }^{20,21}$.

\section{CONCLUSIONS}

Nerve surgery requires special microsurgical training. Experimental microsurgery performed on living rats offer a real experience when it comes to handling life tissue. Nerve defects can be solve only by using different types of nerve conduits, each having advantages and disadvantages. 
Knowing the shortcomings of each conduit (biological or synthetic) and what can be done in each situation is the prerogative to performing a nerve repair with good expected outcomes.
Compliance with ethics requirements: The authors declare no conflict of interest regarding this article. The authors declare that all the procedures and experiments of this study respect the ethical standards in the Helsinki Declaration of 1975 , as revised in 2008(5), as well as the national law. Informed consent was obtained from all the patients included in the study.

12. Christensen TJ, Anding W, Shin AY, Bishop AT, Moran SL. The Influence of Microsurgical Training on the Practice of Hand Surgeons. J Reconstr Microsurg. 2015 Jul;31(6):442-9. doi 10.1055/s-0035-1549443. Epub 2015 Apr 20.

13. Andrei, M., Gabriela, M., Amalia, D., \& Mircea, E. (2019). Learning curve in rat dissection for experimental sciatic nerve repair. Romanian Neurosurgery, 33(3), 243-248. https://doi org/10.33962/roneuro-2019-041

14. Ionescu, M. M., Costea, R., Balint, E., \& Lastofka, D. (2017). Surgery technique models of sciatic nerve allograph in Wistar rats. Abstracts/Journal of Biotechnology 256S, 44, S116

15. Mihai Mehedintu-Ionescu, Ovidiu Stefanescu, Radu Cristian Jecan. Nervous Regeneration Allograph Type of Periferic Nerv. Modern Medicine | 2019, Vol. 26, No. 2

16. Costea Ruxandra, Daniel Lastofka, and Mihai Mehedintu. "Comparison of Ketamine-Medetomidine-butorphanol and Ketamine-dexmedetomidine-butorphanol Anesthesia in Rats." Agriculture and Agricultural Science Procedia 6 (2015): 305-308.

17. Fujimaki $H$, Uchida K, Inoue G, Miyagi M, Nemoto N, Saku T, Isobe $Y$, Inage K, Matsushita O, Yagishita S, Sato J, Takano S, Sakuma Y, Ohtori S, Takahashi K, Takaso M. Oriented collagen tubes combined with basic fibroblast growth factor promote peripheral nerve regeneration in a $15 \mathrm{~mm}$ sciatic nerve defect rat model. J Biomed Mater Res A. 2017 Jan;105(1):8-14. doi: 10.1002/jbm.a.35866. Epub 2016 Aug 21

18. Mohammadi J, Delaviz H, Mohammadi B, Delaviz H, Rad P. Comparison of repair of peripheral nerve transection in predegenerated muscle with and without a vein graft. BMC Neurol. 2016 Nov 22;16(1):237.

19. Manoli T, Schulz L, Stahl S, Jaminet P, Schaller HE. Evaluation of sensory recovery after reconstruction of digital nerves of the hand using muscle-in-vein conduits in comparison to nerve suture or nerve autografting. Microsurgery. 2014 Nov;34(8):60815. doi: 10.1002/micr.22302. Epub 2014 Aug 2.

20. Marin Andrei, Mihai Ruxandra Ioana, Marin Georgiana Gabriela. Pitfalls and problems encountered in rat model sciatic nerve surgery. Romanian Neurosurgery (2019) XXXIII (4): pp. 396399DOI: 10.33962/roneuro-2019-064

21. Moosavizadeh SM, Alizadeh Otaghvar $H$, Baghae $M$, Zavari $A$, Mohyeddin H, Fattahiyan H, Farazmand B, Moosavizadeh SMA. Comparison of conduit and autograft efficiency in repairing femoral nerve injury in New Zealand rabbits. Med J Islam Repub Iran. 2018 Oct 13;32:99. doi: 10.14196/mjiri.32.99. eCollection 2018. 
